\title{
GROUP GUIDANCE WITH FOLKLORE METHOD AS ALTERNATIVE TO DEVELOP TOLERANCE CHARACTER
}

\author{
Sri Hartini, Agus Supriyanto*, Amien Wahyudi, Anwar Sutoyo, Rezki Perdani \\ Sawai, Agungbudiprabowo \\ * Correspondent Author
}

Sri Hartini

Guidance and Counseling Universitas Ahmad Dahlan

Jalan Pramuka Nomor 42, Umbulharjo, Yogyakarta, 55161

Indonesia

Email: sri.hartini@bk.uad.ac.id

Agus Supriyanto

Bimbingan dan Konseling Universitas Ahmad Dahlan

Jalan Pramuka Nomor 42, Umbulharjo, Yogyakarta, 55161

Indonesia

Email: agus.supriyanto@bk.uad.ac.id

Amien Wahyudi

Bimbingan dan Konseling Universitas

Ahmad Dahlan

Jalan Pramuka Nomor 42, Umbulharjo,

Yogyakarta, 55161

Indonesia

Email: amien.wahyudi@bk.uad.ac.id

Anwar Suto

Bimbingan dan Konseling Universitas Negeri Semarang Sekaran, Gunungpati, Semarang city, Central Java, 50229

Email: anwarsutoyo@mail.unnes.ac.id

Agungbudiprabowo

Universitas Ahmad Dahlan

Jalan Ringroad Selatan, Tamanan

Banguntapan, Bantul

Email: agungbudiprabowo@bk.uad.ac.id

Page

39-45

\begin{abstract}
Diversity in Indonesia raises the tolerance problem. The research goal to find guidance and counseling services right to develop character tolerance. The goals of this research is developing of models group gudance with folklore methode as alternative developing tolerance character. This research use Research and development as an approach. Research and development steps include preliminary study, development hypothetical group guidance model-based folklore, validation of expert judgment and expert practitioners, experimental test form group guidance modelbased folklore on a limited basis - descriptive qualitative and descriptive quantitative in research analysis. Group guidance services consisted of 8-9 students from Yogyakarta City, Bantul Regency, Sleman Regency, Kulonpogo Regency, and Gunungkidul Regency (Indonesia Country The result from this research that group guidance with folklore methode can incrase the tolerance character of students. The result of the limited trial appears that there was a change of condition before pre-test with an average of 109 and an increase of 117.9 after post-test in implementation of group guidance service with folklore method. The T-test results also reveal significant changes from before to after the significance of $0.000(<0.05)$.

Keywords: group guidance, folklore, character tolerance
\end{abstract}

\section{INTRODUCTION}

Cultural diversity in Indonesia leads to uniqueness in every society in terms of languages, religions, ethnicities, races, colours, and customs. Complimentary views on variety lead to national unity with many challenges on the disruption era. Positive pictures of cultural diversity can also be viewed negatively as one of them is on when the people can't appreciate the differences and diversity. Monocultural aspects, pluralistic aspects, and socio-cultural geneses become representations from hierarchical of need the content and structure (Sibley et al., 2011). Cultural diversity can legitimize various case discriminatory (Sibley, 2013).

Indonesia, as a country with cultural diversity, requires character development 


\section{0 |PSIKOPEDAGOGIA}

JURNAL BIMBINGAN DAN KONSELING

Vol.9, No.1, June 2020

efforts. The concept of appreciating religious citizenship forms one's identity as a citizen (Laksana \& Wood, 2019). Values in Pancasila can strengthen national character nationally. The struggle to define and hold to a national character as will set the course of the future (Colbert, 2011).

Intolerance in Indonesia involving children and student, particularly those in children's education (Solehuddin, 2019), because of the different political choice and religious (Laksana \& Wood, 2019). The phenomenon of behaviour that doesn't appreciate has an impact on disorderly conduct and misscommunication with social media. Political organizations in the religious field (Front Pembela Islam) during the 2019 presidential election have promoted social morals with followers of a large proportion of the population and encouraged radicalism and acts of violence in the name of Islam, as well as forcing arguments (Facal, 2020). Ethnicity and religion-based conflicts may threaten the future of Indonesian youth (Firdaus et al., 2020). There are also Sunnis and Syiah who have sectarianism to seek electoral matters in Indonesian democracy (Kayane, 2020). At the same time, religious discrimination creates intolerance and self-limitation as citizens.

School counselors plays important role to internalize the tolerance character through guidance and counselling services. School counselors are responsible for developing students' character. Group guidance service with group discussion methods, socio-drama, observation, lectures, and advice are among models for school counsellors to implement in in character education programs (Julia \& Supriyadi, 2018). Culture-based group guidance service may also be useful to develop students' character, as reported stated by Abdi et al. (2019). One of the ways to improve the students' tolerance character could be done through folktale-based character education.

Supporting research results are group guidance as a one way to internalize mutual respect with guidance and counseling functions. The success of activities or interventions of school guidance and counselling programs vary may vary (Whiston et al., 2011). The folk-lore method could be appropriately implemented in guiance and counselling service.

The folklore method in educational programs compares the values of current folklife education with the folktale in the regions as part of intercultural education (Rosenberg, 2019) as well as multicultural guidance and counseling. For instance, a folktale from Malang, which contains the values of character education, tolerance, respect, caring, and love of the country (Malitasari et al., 2013). There are also folk tales in Bali that are useful for educating children's morals based on Pancasila and the values of character education (Suwija et al., 2020). The purpose of this study is to develop a group guidance service model with folklore method that is effective for developing students' tolerance character.

\section{METHODOLOGY}

In this study, research and development method was applied. The final product of this study was folk-lore based group guidance for developing junior high school students' tolerance. Three stages were undertaken :1) Preliminary study on tolerance, which was done by distributing tolerance scale to 739 junior high school students in Special Region of Yogyakarta, Indonesia. 2) Development stage, in this stage the hypothetical model of folk-lore based group guidance was developed. 3) Expert and practitioner validation. 4) The last, The effectiveness test, in this stage, the developed product (i.e., folklore-based group guidance model) was tested experimented. Data analysis in this study used qualitative research conducted by grouping qualitative data information in the form of responses, inputs, and suggestions obtained from the experts, to revise the development of group guidance model with folklore method. In contrast, the results of the discussion and subsequent analysis results in qualitative data is taken into consideration to review the folklore-based group guidance service model Quantitative data analysis was also conducted by descriptively analyzing the result of the preliminary study comparing the pre-test and post-test results. T-test analysis was done to see the effectiveness of folklorebased group guidance method in developing students' tolerance character. In testing the product, 41 students were recruited and assigned into five groups. They come from Yogyakarta City, Bantul Regency, Sleman Regency, Kulonpogo Regency, and Gunungkidul Regency, Indonesia.

\section{RESULT AND DISCUSSION}

The concept of peace refers to the absence of cultural violence that legitimizes direct and structural disorder (Galtung \& 
Fischer, 2013). Three aspects of tolerance was measured during the preliminary studies,they were peace, respect others' difference, and awareness of others (Supriyanto \& Wahyudi, 2017). The findings of a preliminary study with junior high school students totalling $\mathrm{N}=739$ are categories of tolerance characters and classes of each aspect and indicator of tolerance character. The findings indicate that students' peace was categorized as low. The aspect of respect others' dffierence was also categorized as low. The last result of the preliminary study was the self-awareness of individuals in the high class, even though the comfort of themselves was in a subordinate variety.

Table 1.

Result of Character Analysis of Junior High School Student Tolerance in Special Region of Yogyakarta, Indonesia

\begin{tabular}{|c|c|c|c|}
\hline No & $\begin{array}{l}\text { Tolerance } \\
\text { Character }\end{array}$ & $\begin{array}{c}\text { Indicator of } \\
\text { Tolerance Character }\end{array}$ & Criteria \\
\hline \multirow{3}{*}{1} & \multirow{3}{*}{ Peace } & Care & Low \\
\hline & & Fear & High \\
\hline & & Love & Low \\
\hline \multirow{3}{*}{2} & \multirow{2}{*}{$\begin{array}{l}\text { Respect } \\
\text { for } \\
\text { Difference }\end{array}$} & \multirow{2}{*}{$\begin{array}{l}\text { Respect each other } \\
\text { Respect differences of } \\
\text { other }\end{array}$} & Low \\
\hline & & & Low \\
\hline & S and & Respect ourselves & Low \\
\hline \multirow{5}{*}{3} & \multirow{5}{*}{$\begin{array}{l}\text { Awwernes } \\
\text { s }\end{array}$} & $\begin{array}{l}\text { Appreciating the } \\
\text { goodness of other }\end{array}$ & High \\
\hline & & Open & High \\
\hline & & Receptive & High \\
\hline & & Comfort in Life & Low \\
\hline & & Comfort with other & High \\
\hline
\end{tabular}

Experts and practitioners suggested that the developed product should be used using various method. Guidance and counseling services plays pivotal role in internalizing the meaning of life to the students (Alhadi et al., 2016). Extensive group guidance can address character problems through various methods. Professional school counselors graduated from the teacher professional education program, have the expertise to apply useful techniques to improve the students' multicultural competence through guidance and counselling programs (Galassi et al., 2008; Sink \& Edwards, 2008; Van Velsor, 2009). The group guidance was carried out based on the students' developmental tasks. Its process provided participant with huge opportunities to develop their tolerance character.

Folklore method could be used in group in order to develop students' tolerance. Folklore in education program can develop students' character of peace, self-awareness, and respect. The tolerance character makes up the individual the ethnic identity as the community awareness in social groups part of the Indonesian nation.

Guide implementation from group guidance service with folklore method group according to the implementation procedure. Implementation procedures arranged following the results of the literature review. Stages of activities in the group, namely (1) the set of formation, (2) the exploration stage, (3) the regulatory phase, (4) the stage of implementation/work, and (5) termination stage (Schmidt, 2008). The goal of group guidance service is the formation of relationships that influence each other between individuals and group members as a whole (Jansen et al., 2020).

The character of values and culture in folklore fosters the attitude and personality of tolerance in students. This concept is corresponding with the results of other studies that the group guidance service based on Javanese local character values can be an alternative to maximize the quality of guidance services (Dewi, 2016). Folklore, as an oral tradition and cultural heritage, has the potential as an alternative to cultivating the noble values of education in student life (Huda, 2018; Rosa, 2019).

Teachers have a role as a model children, when the role is well-implemented, a caring community could be realized. A caring community may result in lower bullying behavior and higher academic achievement (Marshall et al., 2011; Parker et al., 2010). Schools have a typical role in developing students' character. School counselor play a role to internalize the tolerance character values of life in their students, teaching them about differences that constitute the national identity. Effective reinforcement, intellectual attitudes may affect the development of social beliefs, social skills, and spiritual attitudes of students (Trisiana, 2015; Wang, 2017).

Various folklore in Indonesia could be used in group guidance services. Counselors tell folktales selected in the topic assignment or student reading folklore discuss to find the meaning of tolerance. Indonesian folk tales can be said to develop the tolerance character that story of Roro Jonggrang, Legend of Ciung Wanara, Legend of Rawa Pening, and then Story of Lutung Kasarung. Folklore in Jonggrang, these stories imples that one should not force his belief/choice against others' (Setyaningsih, 2016). 


\title{
42 |PSIKOPEDAGOGIA
}

\author{
JURNAL BIMBINGAN DAN KONSELING
}

Vol.9, No.1, June 2020

Imposing one's political preference to others' could be seen as human right violation. Ciung Wanara story also rich in moral values and culture of Indonesia, one of which can accept the advantages of others and any greed to power would bring disaster (Arifin, 2013). Mutual respect appearing in the Rawa Pening Legend reminds people to understand each other despite the differences (Seftyono, 2014). Reinforcement in Legend of Lutung Kasarung implies that God creates difference to teach people respect each others (Isnendes \& Haerudin, 2011).

The final stage is an experimental trial involving 41 junior high school students. One group of group guidance service consisted of 8-9 students from Yogyakarta City, Bantul Regency, Sleman Regency, Kulonpogo Regency, and Gunungkidul Regency. The result of the experiment indicate a positive change after the treatment was given. This change was shown by the difference in preand post-test score(109 and117.9). The Ttest results also indicated significant changes after the treatment was given $(0.000<0.05)$. In short, students' tolerance character could be developed using folklore-based group guidance service.

Table 2.

Differences Pre-Test and Post-Test in Development of Tolerance Character

\begin{tabular}{ccccc}
\hline & $\begin{array}{c}\text { Mean from } \\
\text { Tolerance } \\
\text { Character }\end{array}$ & N & $\begin{array}{c}\text { Std. } \\
\text { Deviation }\end{array}$ & $\begin{array}{c}\text { Std } \\
\text { Mean }\end{array}$ \\
\hline $\begin{array}{c}\text { Pre test } \\
\text { Post } \\
\text { test }\end{array}$ & $\mathbf{1 0 9 , 0 0 0 0}$ & 41 & 5,63915 & 0,88069 \\
\hline
\end{tabular}

The results of the research findings are three aspects of tolerance in the form of characteristics of peace, aspects of care, and aspects of mutual respect. These three aspects are the conclusion of various theoretical concepts with the conditions of Indonesian society. Tolerance means appreciating, allowing, allowing the opinion, views, beliefs, habits, behaviour, etc., that are otherwise or contrary to its founders, such as religions, ideology, and races-the tolerance character as an attitude of mutual respect through understanding with the aim of peace. Tolerance is toward peace. Peace creates a peaceful mind (Tillman, 2004). These reflection points of tolerance character will deliver peace between individuals in the world. Character education becomes the main foundation in fostering the essence of Indonesian nation through education.

The tolerance character is a character that is indicated by human attitudes and behaviour that don't deviate from the rules, in which a person appreciates or respects every action that others do. Tolerance is called the essential factor for peace. The meaning of peace as an internal human condition has a peaceful mind to itself when happening certain situations (Galtung \& Fischer, 2013).

Group guidance services apply on a folklore basis can developing student tolerance character. Various folk tales in Indonesia have story characters with the messages of the stories. Folklore is a collection of main stories with core messages to form addictive behaviour towards a culture that is implemented in education and easily implemented in the teaching and learning process (Relin et al., 2018; Vuong et al., 2018). Folktale is a legacy from generation to generation, orally and written (Hutomo, 1991). And then, folktale presented by the counsellor as a group leader and discussed with members to the group to develop a tolerance character.

First, the stage to form a crowd of individuals into a group that is ready to develop group dynamics in achieving common goals. Second, the stage to divert the group's initial activities to the next action that is more focused on achieving group goals. Third, the core activity stage to discuss specific topics with folktale method as service media and method. Fourth, the stage of action to review what the group has done and achieved. Group participants apply reflect on the activities with messages from folklore to the development of a character of tolerance. The last is the closing all activities. The group guidance service with folklore method used of five stages. The steps in group guidance are formation, transitional, activity, inference, and closing (Supriyanto \& Wahyudi, 2018). The different stages of this model are the emergence of folklore media in the activity stage of implementing group guidance services. The development of tolerance character from research results is following the implementation of character education administration from planning, performance, and control (Pangaribuan et al., 2020).

\section{CONCLUSION}

Students' tolerance level in Yogyakarta was categorized as low. The peace aspects 
of and mutual respects our differences and individual aspects of Indonesian students in the low category. While the self-awareness aspects of students in the high class, although the comfort of oneself in the low sort. The development of tolerance character needs to apply in cognitive, affective, and psychomotor in students with indicators of peace, respect, and individuality, and awareness-group guidance model with folklore method as an alternative to the development of the tolerance character in students. Folklore is pass down from one generation to the next generation, orally and in written according to the peculiarities of the Indonesian Country. The group guidance service with folk consists of five stages. The steps in group guidance are formation, transitional, activity, inference, and closingapplication of folklore in group guidance services at the activity stage. Group guidance services folklore methods can be applied by school counselors to develop tolerance character through folklore books. Using this model, counselors tell folktales selected in the topic assignment or student reading folklore, then the students discuss to find the meaning of tolerance. Some Indonesian folk tales that are recommended to be used to develop the tolerance character are story of Roro Jonggrang, Legend of Ciung Wanara, Legend of Rawa Pening, and Story of Lutung Kasarung. Development of mutual respect emerges as a part of developing the tolerance character.

\section{ACKNOWLEDGEMENT}

This research fully supported by Affiliation Research Grant Ministry of Research and Technology Dikti, Indonesia.

\section{REFERENCES}

Abdi, S., Sugiharto, D. Y. P., \& Sutoyo, A. S. A. (2019). Group guidance based on gayo ethnics' cultural values to improve students' islamic characters. Jurnal Bimbingan Konseling, 8(2), 112-118.

Alhadi, S., Supriyanto, A., \& Dina, D. A. M. (2016). Media in guidance and counseling services: A tool and innovation for school counselor. SCHOULID: Indonesian Journal of School Counseling, 1(1), 6-11.

Arifin, C. Y. (2013). Perancangan buku cerita rakyat ciung wanara. [PhD Thesis]. Universitas Kristen Maranatha.
Colbert, C. R. (2011). National character vs. national security: Conflict in the making? Army war coll carlisle barracks $P A$.

Dewi, N. K. (2016). Pengembangan model bimbingan kelompok berbasis nilai karakter lokal jawa untuk meningkatkan kesadaran diri (self awareness) siswa. Counsellia: Jurnal Bimbingan Dan Konseling, 3(1).

Facal, G. (2020). Islamic defenders front militia (front pembela islam) and its impact on growing religious intolerance in indonesia. TRaNS: Trans-Regional and-National Studies of Southeast Asia, 8(1), 7-20.

Firdaus, F., Anggreta, D. K., \& Yasin, F. (2020). Internalizing multiculturalism values through education: Anticipatory strategies for multicultural problems and intolerance in Indonesia. Jurnal Antropologi: Isu-Isu Sosial Budaya, 22(1), 131-141.

Galassi, J. P., Griffin, D., \& Akos, P. (2008). Strengths-based school counseling

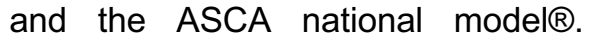
Professional School Counseling, 12(2), $2156759 \times 0801200207$.

Galtung, J., \& Fischer, D. (2013). Positive and negative peace. In Johan Galtung (pp. 173-178). Springer.

Huda, M. (2018). Humanistic learning in folklore of surakarta. Profunedu International Conference Proceeding, 1, 7-12.

Hutomo, S. S. (1991). Mutiara yang terlupakan: Pengantar studi sastra lisan. Himpunan Sarjana Kesusastraan Indonesia, Komisariat Jawa Timur.

Isnendes, R., \& Haerudin, D. (2011). A Discourse of the female body in an ancient sundanese literary work of lutung kasarung: An eco-feminist approach. TAWARIKH, 3(1).

Jansen, W. S., Meeussen, L., Jetten, J., \& Ellemers, N. (2020). Negotiating inclusion: Revealing the dynamic interplay between individual and group inclusion goals. European Journal of Social Psychology, 50(3), 520-533.

Julia, J., \& Supriyadi, T. (2018). The implementation of character education at senior high school. Online Submission, 42. 


\section{4 |PSIKOPEDAGOGIA}

JURNAL BIMBINGAN DAN KONSELING

Vol.9, No.1, June 2020

Kayane, Y. (2020). Understanding sunnishi'a sectarianism in contemporary indonesia: A different voice from nahdlatul ulama under pluralist leadership. Indonesia and the Malay World, 48(140), 78-96.

Laksana, B. K., \& Wood, B. E. (2019). Navigating religious diversity: Exploring young people's lived religious citizenship in Indonesia. Journal of Youth Studies, 22(6), 807-823.

Malitasari, N., Rus Andianto, M., \& Husniah, F. (2013). Nilai-nilai pendidikan karakter dalam cerita rakyat Malang. Universitas Jember.

Marshall, J. C., Caldwell, S. D., \& Foster, J. (2011). Moral education the character plus way®. Journal of Moral Education, 40(1), 51-72.

Pangaribuan, W., Ambarita, B., \& Ginting, Y. (2020). Character based education administration model in senior high school santa maria Kabanjahe, Karo Regency. Journal of Transformative Education and Educational Leadership, 1(2), 66-80.

Parker, D. C., Nelson, J. S., \& Burns, M. K. (2010). Comparison of correlates of classroom behavior problems in schools with and without a schoolwide character education program. Psychology in the Schools, 47(8), 817-827.

Relin, R., Rasna, I. W., \& Binawati, W. S. (2018). Local wisdom values in balinese folktales that are relevant to character education for the first grade at primary school. Journal of Language Teaching and Research, 9(1), 155-163.

Rosa, S. (2019). Teaching character through oral stories in indonesia and malaysia. Jati-Journal of Southeast Asian Studies, 24(2), 176-190.

Rosenberg, J. (2019). Conclusions: The past is prologue: Notes for understanding folklore and education considering the pedagogy of rachel davis DuBois. In Intercultural Education, Folklore, and the Pedagogical Thought of Rachel Davis DuBois (pp. 119-136). Springer.

Schmidt, J. J. (2008). Counseling in schools: Comprehensive programs of responsive services for all students. Pearson/Allyn and Bacon.
Seftyono, C. (2014). Rawa pening dalam perspektif politik lingkungan: sebuah kajian awal. Indonesian Journal of Conservation, 3(1).

Setyaningsih, L. (2016). Cerita Rakyat "Rawa Pening": Kajian pascakolonial.

Sibley, C. G. (2013). Social dominance and representations of the national prototype: The exclusionary emphasis hypothesis of national character. International Journal of Intercultural Relations, 37(2), 212224.

Sibley, C. G., Hoverd, W. J., \& Liu, J. H. (2011). Pluralistic and monocultural facets of New Zealand national character and identity. New Zealand Journal of Psychology (Online), 40(3), 19.

Sink, C. A., \& Edwards, C. (2008). Supportive learning communities and the transformative role of professional school counselors. Professional School Counseling, 12(2), $2156759 \times 0801200217$.

Solehuddin, M. (2019). Sustainable counselling values by indonesian preschool teachers to prepare more tolerant young global citizens. JOMSIGN: Journal of Multicultural Studies in Guidance and Counseling, 3(2), 119-136.

Supriyanto, A., \& Wahyudi, A. (2017). Skala karakter toleransi: Konsep dan operasional aspek kedamaian, menghargai perbedaan dan kesadaran individu. Counsellia: Jurnal Bimbingan Dan Konseling, 7(2), 61-70.

Supriyanto, A., \& Wahyudi, A. (2018). Group guidance services based on folklore for students junior high school. International Journal of Indonesian Education and Teaching (IJIET), 2(1), 37-46.

Suwija, I. N., Darmada, I., Mulyawan, I., \& Suryasa, W. (2020). Character education value of ending king sexual cruelty on $\mathrm{Ni}$ Dyah Tantri story. Journal of Talent Development and Excellence, 12(2s), 737-745.

Tillman, D. (2004). Pendidikan nilai untuk kaum muda dewasa (Terjemahan Risa Pratono). Jakarta: Grasindo.

Trisiana, A. (2015). Action for citizenship education of character education using project citizen model at senior high school in Indonesia. 
International Journal of Education and Psychology in the Community (IJEPC), 1(2), 42-53.

Van Velsor, P. (2009). School counselors as social-emotional learning consultants: Where do we begin? Professional School Counseling, 13(1), 2156759X0901300106.

Vuong, Q.-H., Bui, Q.-K., La, V.-P., Vuong, T.-T., Nguyen, V.-H. T., Ho, M.-T., Nguyen, H.-K. T., \& Ho, M.-T. (2018). Cultural additivity: Behavioural insights from the interaction of confucianism, Buddhism and Taoism in folktales. Palgrave Communications, 4(1), 115.

Wang, L. (2017). What does it mean to be canadian? building national identity for secondary students through history.

Whiston, S. C., Tai, W. L., Rahardja, D., \& Eder, K. (2011). School counseling outcome: A meta-analytic examination of interventions. Journal of Counseling \& Development, 89(1), 37-55. 